tionsvorgang als solchen. Insofern geraten nationale und lokale Kulturen in Streit mit der globalen Kultur, die im Prinzip alle Identitätsbildung in kontingente Kommunikation auflöst.

Bogdan Zeler (Schlesische Universität Katowice) befasste sich mit „Literatur als Bestimmung (polnischer) Volksidentität und globaler Identität in der Zeit des Internets“. Er zeigte die Bedeutung der Bildung einer Nationalliteratur im 19. Jahrhundert für das entstehende polnische Nationalbewusstsein auf und wie durch die Identifikation mit der Literatur, aber auch in der Literatur selbst Bedingungen für eine Volksidentität geschaffen worden sind. Erst dadurch war es für Polen möglich, Selbstfindungsprozesse einzuleiten und über eine gemeinsame Sprache eine kulturelle Identität auszubilden. Dieser Bezugspunkt scheint heute durch die Globalisierungsprozesse und insbesondere durch den massenweisen Zugang zum Internet in Gefahr zu sein. Literatur werde nicht mehr als Nationalliteratur wahrgenommen, sondern im steigenden Maß nur noch als Weltliteratur. Gleichzeitig habe sie aber auch ihre Funktion für die Bildung von Gemeinschaftsbewusstsein verloren und werde durch die elektronischen Medien marginalisiert, wobei diese immer stärker ein diffuses Weltgefühl verbreiteten, das die nationalen Grenzen transzendiert.

Das Symposium wurde mit der Vorstellung eines Forschungsantrages an die European Science Foundation von Andreas Metzner-Szigeth (Universität Münster) „Proposal for the European Science Foundation in order to support an Exploratory Workshop on Computer-Mediated Communication and European Cultural Diversity” beendet. Der Workshop ist für Mitte 2005 geplant. Er soll drei Themen gewidmet werden: der Wechselwirkung von kultureller Transformation und digitalisierter Kommunikation, neuen Mustern von Identitäts- und Gemeinschaftsbildung im Internet und ihrer kulturellen Bedeutung sowie die Bedeutung der computer-mediatisierten Kommunikation für die kulturelle Diversität und Integration Europas.

Der nächste Workshop des CULTMEDIANetzwerkes findet vom 1.10-3.10. 2004 in Budapest statt. Ab Herbst 2004 wird im trafoVerlag, Berlin, die CultMediA-Publikationsreihe gestartet.

\section{ANKÜNDIGUNGEN / EVENTS}

\section{Ubiquitous Computing - Leben und Arbeiten in der "smarten" Welt \\ Ringvorlesung aus der Reihe Tech- nikfolgenabschätzung}

Universität Stuttgart, Sommersemester 2004

Die Vorlesungsreihe steht unter der Leitung von Prof. Dr.-Ing. Dieter Spath, Institut für Arbeitswissenschaft und Technologiemanagement der Universität Stuttgart, in Zusammenarbeit mit dem Studium Generale der Universität. Die Vorlesungen finden jeweils dienstags von 15.45 - 17.15 statt, Beginn ist Dienstag, der 20. April 2004.

\section{Dienstag, 20. April 2004}

Prof. Dr.-Ing. Dieter Spath: „Ubiquitous Computing - Leben und Arbeiten in der ,smarten' Welt“

\section{Dienstag, 27. April 2004}

Dr. rer. soc. Josephine Hofmann: „Telemanagement in virtuellen Organisationen“

Dienstag, 4. Mai 2004

Dr. phil. Michael M. Zwick: „Wie umstritten ist der Mobilfunk? Zur gesellschaftlichen Wahrnehmung einer Alltagstechnik“

Dienstag, 11. Mai 2004

Dr. phil. Barbara Klein: „E-Health - Mobilkommunikation im Gesundheitswesen“

Dienstag, 18. Mai 2004

Prof. Dr. phil. habil. Christoph Hubig: „Chancen und Risiken einer Veränderung unserer Wirklichkeitsbezüge in intelligenten Umwelten“ 
Dienstag, 25. Mai 2004

Dr.-Ing. Edwin Vogt „Wearable Computing Teil eines Weges in die ,smarte Welt”“

Dienstag, 8. Juni 2004

Dr. phil. nat. Christian Becker: „'Ubiquitous Computing' - Unterstützung durch Kontextmodelle und Peer-to-Peer basierte Systemsoftware“

\section{Dienstag, 15. Juni 2004}

Dr. rer. nat. Frank Heidmann: „Usability issues of Ubiquitous Computing“

\section{Dienstag, 22. Juni 2004}

Dr. rer. nat. Werner Weber: „Ambient Intelligence - Elektronische Dienstleistungen im Informationszeitalter“

Dienstag, 29. Juni 2004

Dipl.-Inf. wiss., Dipl.-Betriebswirt Alexander Greisle: „OFFICE 21® - Zukunft der Arbeit. Gestaltung von Ubiquitous Computing für die Arbeitswelt von morgen“

Dienstag, 6. Juli 2004

Dr.-Ing. Michael Beigl: „Einsatzmöglichkeiten ubiquitärer Informationstechnologien im kontextsensitiven Environment“

\section{Weitere Informationen}

Dipl.-Kfm.t.o. Götz Schwammekrug

Fraunhofer IAO

Nobelstraße 12, 70569 Stuttgart

Tel.: +49 (0) 711 / 970 - 2028

Fax: +49 (0) 711 / 970 - 2299

E-Mail: goetz.schwammekrug@iao.fraunhofer.de Internet: http://www.iao.fhg.de/; http://www.iat.unistuttgart.de/TA.html

\section{Fernstudien-Angebote zu Um- weltthemen}

\author{
Universität Koblenz-Landau, Wintersemes- \\ ter 2004/05
}

Die vom Zentrum für Fernstudien und Universitäre Weiterbildung der Universität KoblenzLandau seit Jahren angebotenen Fernstudienund Weiterbildungsmaßnahmen aus dem Umweltbereich erfreuen sich einer zunehmenden Nachfrage innerhalb der Angebote wissenschaftlicher Weiterbildung deutscher Hochschulen. Nachdem im vergangenen Wintersemester 80 TeilnehmerInnen aus dem gesamten Bundesgebiet zwei parallele Kurse zur Europäischen Wasserrahmenrichtlinie besucht haben, ist im Sommersemester 2004 auch der Kurs „Europäisches Umweltrecht“ mit über 40 Studierenden aus Deutschland und dem europäischen Ausland vollständig ausgebucht.

Die Fortschritte in Umwelttechnologie und Umweltrecht, insbesondere wenn sie von der Europäischen Umweltpolitik geprägt werden, erweisen sich damit als nach wie vor impulsgebend für den Weiterbildungsmarkt im Umweltsektor. Neben dieser thematischen Aktualität ist der Erfolg der Koblenzer Angebote sicherlich auch im Konzept der Maßnahmen begründet: Klassische Fernstudien- und Präsenzelemente ergänzt um moderne Möglichkeiten des Online-Studiums eröffnen den TeilnehmerInnen ein hohes Maß an zeitlicher Flexibilität und räumlicher Unabhängigkeit bei der Erarbeitung der Lerninhalte.

Auch für das Wintersemester 2004/05 können sich Interessierte beim Fernstudienzentrum der Universität Koblenz-Landau wieder für diverse Programme bewerben. Der 1-semestrige Fernstudien-Kurs zur „Europäischen Wasserrahmenrichtlinie“ wird ebenso erneut im Angebot stehen wie der abschlussorientierte, 4-semestrige Diplom- Fernstudiengang „Angewandte Umweltwissenschaften“. Daneben bietet die Universität anerkannte Lehrgänge für Abfall- und für Gewässerschutzbeauftragte per Fernstudium an. Zugangsvoraussetzung ist i. d. R. ein Hochschulabschluss einer ingenieur- oder naturwissenschaftlichen Fachrichtung, doch auch Absolventen anderer Fakultäten oder Berufstätige im 
Umweltbereich ohne akademischen Grad können im Einzelfall zugelassen werden.

Anmeldeschluss für das kommende Wintersemester ist der 15. August 2004.

(Pressemitteilung)

\section{Weitere Informationen erteilt:}

Universität Koblenz-Landau

Zentrum für Fernstudien und Universitäre Weiter-

bildung (ZFUW)

Postfach 2016 02, 56016 Koblenz

Tel.: +49 (0) 261 / 287 - 1520 oder - 1522

Fax: +49 (0) 261 / 287 - 1521

E-Mail: info@umwelt-studium.de oder zfuww@uni-koblenz.de

Internet: http://www.zfuw.uni-koblenz.de/

》)

\section{Foresight Training Course 2004 Foresight Training for Practitioners and Organisers}

\author{
PREST, University of Manchester, UK, \\ June 28 - July 2, 2004
}

Now in its sixth year, the annual PREST Foresight training course provides an intensive, practically-oriented introduction to Foresight for those who might be involved in Foresight activities, whether as a sponsor, organiser or practitioner. Past attendees have included senior managers and practitioners from companies, intergovernmental organisations, research institutes, and government departments. The course is residential and is organised around parallel streams of lectures and practical work that enables participants to experience the relevance of each lecture and the realities of Foresight activity.

The course draws upon PREST's extensive experience of organising and researching Foresight activities across Europe and beyond. This includes direct assistance to more than a dozen countries' national Foresight exercises, close cooperation with the EC and UNIDO, and facilitating Foresight activities in public and private organisations.

The course runs over five days and covers the following main areas:
- Day 1 - thinking about the future; rationales and objectives of Foresight; introduction to Foresight methods

- Day 2 - environmental scanning; forecasting; Delphi; creative methods

- Day 3 - developing and using scenarios; fitting things together - the methods 'jigsaw'

- Day 4 - planning a foresight exercise; future technological prospects; social foresight; regional and national foresight case studies

- Day 5 - Foresight outputs, implementation, and evaluation; forum on the future of Foresight; practical session presentations

PREST teachers include Luke Georghiou, Michael Keenan, Graham May, Ian Miles, Rafael Popper, and Ozcan Saritas. PREST staff will be joined by 5-6 external speakers with distinctive Foresight experiences to relay.

\section{Further information can be obtained from}

Lisa Moore

PREST, The University of Manchester

Oxford Road, Manchester M13 9PL, UK

Tel.: +44 (0) 161 - 275 - 5921

Fax: +44 (0) 161 - 275 - 0923

E-Mail: Lisa.Moore@man.ac.uk

Further details of this year's Foresight Training Course at PREST, together with application form, are now available online at http://les.man.ac.uk/ PREST/Teaching/Short_Courses/Foresight.html

\section{International conference on technology transfer and inno- vation}

\author{
Edinburgh, UK, June 29 - July 1, 2004
}

Technology transfer and innovation 2004 (tti2004), a major international conference on innovation and knowledge transfer, will take place from June 29 to July 1 in Edinburgh, UK. The event will enable innovation managers and implementers from industry, academia and the public sector to: 
- view leading edge research initiatives from around the globe;

- see research ideas turned into commercial competitive advantage;

- extend networks of professional contacts and identify potential partners;

- address current issues in knowledge transfer.

The conference will feature speakers from government, industry and research, addressing daily themes such as market needs and knowledge development, the challenge of exploiting knowledge, and business in a changing environment.

(Source: CORDIS focus)

For further information, please consult the following web address:

http://www.tti-ltd.com/tti2004/

》

\section{Conference on sustainable ur- ban management and land use - research to application}

Prague, Czech Republic, July 1-2, 2004

The European Commission's DG Research, together with the Senate of the Czech Republic, is organising a conference entitled "Sustainable urban management and land use from European research to application at the local level" to take place in Prague, Czech Republic, on 1 and 2 July.

The event has two key objectives. First, to encourage the dissemination and uptake of results from Fifth Framework Programme (FP5) research projects on sustainable urban management and land use, promoting the transfer of knowledge to practitioners and policy makers alike.

Second, the conference will seek to promote participation in FP6 under the 'Global change and ecosystems' and 'Scientific support to policy' priorities, with a special focus on the ten new EU Member States, as well as the candidate countries.
To register for the conference, please consult the following web address:

http://scic.cec.eu.int/scic/owa/WEB_MTKF.reg _form?confID=0412PRAGUE

For further information, please contact:

Mr Viorel Vulturescu

European Commission

Directorate-General for Research (office LX46-

02/59), B-1049 Brussels

Tel.: +32 - 2 - 2964684

E-Mail: viorel.vulturescu@cec.eu.int

\section{International conference on ICT in education}

\author{
Samos Island, Greece, July 1 - 3, 2004
}

The fifth international conference on the use of information and communication technologies (ICT) in education will take place from July 1 to 3 on Samos Island, Greece.

Through a series of keynote addresses, plenary sessions, workshops, and fora, the conference will seek to address the many challenges and new opportunities presented by technological innovations in educational settings.

Conference themes will include:

- institutional and national responses to technological change;

- the architecture of learning; accessibility; the evolution of the classroom;

- intellectual property;

- ethical considerations in the use of information technology in teaching and learning.

(Source: CORDIS focus)

For further information, please consult the following web address:

http://www.ineag.gr/ICICTE/

(Source: CORDIS focus) 


\section{Kybernetik - Geschichte einer transdisziplinären Anstrengung}

\author{
Berlin, 2. - 3.Juli 2004
}

Ein Workshop des Berliner Stiftungsverbundkollegs der Alcatel SEL Stiftung an der HUMBOLDT-UNIVERSITÄT ZU BERLIN

\section{Alcatel SEL Stiftung}

Die gemeinnützige Alcatel SEL Stiftung für Kommunikationsforschung im Stifterverband für die Deutsche Wissenschaft fördert seit über zwei Jahrzehnten hervorragende wissenschaftliche Arbeiten, die zur Verbesserung der Interaktion von Mensch und Technik in Kommunikationssystemen beitragen. Die Stiftung verleiht jährlich den mit 20.000 Euro dotierten „Forschungspreis Technische Kommunikation“ und vergibt jährliche Dissertationsauszeichnungen für die besten Ökonomie-Arbeiten zum Themengebiet der Kommunikationstechnik und deren Anwendungen. Mit Veranstaltungen - vom Workshop bis zu Kongressen - beteiligt sie sich intensiv an der Gestaltungsdiskussion über Neue Medien. An den Universitäten Darmstadt, Stuttgart und Dresden engagiert sich die Stiftung seit vielen Jahren mit Stiftungskollegs. Mit dem neu gegründeten Stiftungs-Verbundkolleg Berlin zum Themenbereich Informationsgesellschaft wird ein weiteres interdisziplinäres Projekt, aber auch erstmals die hochschulübergreifende Kooperation zum Themenbereich gefördert. Der Vorstand des Stuttgarter Stifterunternehmens Alcatel SEL AG setzt mit der Gründung des Verbundkollegs Berlin ein Signal für sein Engagement für die Wissenschaft am Standort Berlin.

\section{Stiftungsverbundkolleg Berlin}

Das Alcatel SEL Stiftungs-Verbundkolleg Berlin fördert die Wissenschaft im Themenbereich Informationsgesellschaft, zu dem im interdisziplinären Rahmen an den Berliner Hochschulen übergreifend Lehrveranstaltungen, Kolloquien, Vorträge, Hearings, Konferenzen und Publikationen angeboten werden.
Vortragende auf dem 1. Workshop des Stiftungsverbundkollegs zum Thema „Kybernetik - Geschichte einer transdisziplinären Anstrengung" sind:

Prof. Dr. Dr. h.c. Wilfried Brauer, Technische Universität München, Informatik; Prof. Dr. Lothar Budach, Universität Potsdam, Informatik; Prof. Dr. Wolfgang Coy, Humboldt-Universität zu Berlin, Informatik; Prof. em. Dr. Dr. h.c. mult. Günter Hotz, Universität des Saarlandes, Informatik; Prof. Dr. Frieder Nake, Universität Bremen, Informatik; Prof. Dr. Claus Pias, Universität Essen, Medienwissenschaften; Prof. em. Dr. Dr. h.c. mult. Günter Tembrock, HumboldtUniversität zu Berlin, Biologie

\section{Kontaktadresse}

Alcatel SEL Stiftung

Lorenzstr. 10, 70435 Stuttgart

Tel.: +49 (0) 711 / 821 - 45002

E-Mail: sel.stiftung@alcatel.de

Internet: http://www.alcatel.de/stiftung

\section{Anmeldung}

Um Anmeldung mit Namen und Adresse wird gebeten per E-Mail an alcatel@waste.de oder per Fax unter 03020933168.

Weiteres unter:

http://waste.informatik.hu-berlin.de/Tagungen/ $\mathrm{Kyb} /$ index.html

\section{Science and Democracy Net- work Annual Meeting}

\author{
Harvard University, Cambridge, MA, USA, \\ July 22-24, 2004
}

The Program on Science, Technology, and Society at Harvard University's John F. Kennedy School of Government will host the third annual meeting of the Science and Democracy Network on Thursday-Saturday, July 22-24, 2004. 
The workshop will be organized around the following three themes:

- Institutions: Role of governmental and nongovernmental institutions, including NGOs, corporations, international governmental organizations, scientific institutions, and the state and its agencies.

- Citizenship and Participation: Forms and modes of citizen mobilization and expression, including (new) social movements, new forms of participation, consumer activism, patient groups, indigenous peoples, and "liminal citizens" (endangered species, animals, embryos, and stem cells, for example).

- Communication and Representation: Political discourses, expert and professional discourses, mass media, visual representation, information and communication technologies, databases, identification technologies, etc.

Under each theme, priority will be given to work focusing on issues of uncertainty which have gained significance in various theoretical and practical contexts. The concept of uncertainty will be broadly construed to include work on risk, precaution, disasters, scientific or medical uncertainty and ignorance, public skepticism toward or loss of trust in experts, uncertainty in science communication, etc.

\section{You may address your abstracts or re- quests to attend to}

constance_kowtna@harvard.edu.

"

\section{STILE - European conference Measuring the Information Society}

\section{Brussels, Belgium, September 30 - October 1, 2004}

With funding from the European Commission's Information Society Technology (IST) Programme in collaboration with Eurostat, the STILE project was set up to provide innovative methodologies and content for the statistical monitoring of the European labour market in the eEconomy.

This conference aims at presenting the main results from the three years' project to a broad audience of statisticians, policy makers and researchers, concerned with the issues of a better understanding and monitoring of the labour market in the New Economy. International experts are invited to reflect on the project issues from methodological, theoretical and policy perspectives, thus challenging and complementing the STILE results.

\section{Conference topics}

The core themes are:

- Labour market mobility in the old and the new economy: the hard figures

- Occupations in the Information Age: how to understand?

- Organisation panel surveys in Europe: towards more convergence

- Coding and classifications: the blind spots are mapped

- eWork: common understandings and new realities

Each topic will include:

- STILE results

- Theoretical and conceptual reflections

- Methodological contributions

- Policy views

presented by outstanding experts and stakeholders.

The conference language is English.

You can find the detailed programme and all practical information on the conference on the STILE website, http://www.stile.be/ conference.htm.

You can also find the latest news on the STILE project in the latest issue of our project's Newsletter via our project website, http://www.stile.be/newsletters.htm.

We hope that you find it interesting and that it may stimulate you to learn more about the final results that will be presented at the conference. 


\section{For more information about the scientific programme, please contact:}

Monique Ramioul

STILE project co-ordinator

Higher Institute for Labour Studies (HIVA)

Katholieke Universiteit Leuven

Atrechtcollege

Naamsestraat 63, B-3000 Leuven, Belgium

E-Mail: monique.ramioul@hiva.kuleuven.ac.be

\section{For practical information, please contact:}

Sandra Volders

Higher Institute for Labour Studies (HIVA)

Katholieke Universiteit Leuven

Atrechtcollege

Naamsestraat 63, B-3000 Leuven, Belgium

Tel.: +32 16324355

Fax: +32 16324354

E-Mail: sandra.volders@hiva.kuleuven.ac.be

॥

\section{UVP-Kongress}

Instrumente der Umweltfolgenprüfung - Integration oder Dissonanz?

Potsdam, 6. - 9. Oktober 2004

\section{Der Anlass}

Zum 7. UVP-Kongress 2004 lädt die UVPGesellschaft e.V. die Fachwelt nach Potsdam ein. Angesprochen sind Angehörige der Öffentlichen Verwaltung, Vertreter der Politik, Fachleute aus Universitäten und Fachhochschulen, Fachverbänden sowie Ingenieurbüros, die in Deutschland, Österreich und den Beitrittsländern auf den verschiedenen Ebenen mit den Themen Umwelt und Planung befasst sind.

\section{Die Themen}

In Fortsetzung des sehr erfolgreichen 6. UVPKongresses 2002 in Hamm (Westf.) sowie früherer UVP-Kongresse in Freiburg und Dresden hat der 7. UVP-Kongress 2004 die hochaktuelle Umsetzung der SUP (Strategi- sche Umweltprüfung)-Richtlinie zum Kernthema. Insbesondere sollen Möglichkeiten und Wege zur Verknüpfung und Abstimmung der bereits bestehenden nationalen (z. B. Landschaftsplanung in Deutschland) sowie auch internationalen (z. B. UVP und FFH (Fauna, Flora, Habitat)-Verträglichkeitsprüfung) Instrumente der Umweltprüfung mit den neuen Bestimmungen zur SUP aufgezeigt werden. Diese Zusammenführung wirft viele Fragen auf: Welche Inhalte sind auf welcher Planungsebene zu prüfen (Abschichtung)? Wie müssen die unterschiedlichen Rechtsfolgen beachtet werden? Wie steht die Landschaftsplanung zur SUP? Übernimmt der Planer selbst die SUP zu seinen Planungsinhalten? Welche Kontrollinstanzen sollten entstehen? Wie soll die Öffentlichkeit beteiligt werden?

Ein zweiter Schwerpunkt im Jahr der EUErweiterung liegt im Blick über die alten Grenzen nach Osten. Der diesjährige Kongress wird die Möglichkeit eröffnen, Informationsaustausch und Zusammenarbeit mit neuen Mitgliedstaaten $\mathrm{zu}$ intensivieren und auszubauen. Gegenseitiger Informationsaustausch ist besonders zur laufenden Umsetzung der SUP sowie den internationalen Konventionen im Umweltbereich wie Biodiversitäts-Konvention, Europäischer Landschafts-Konvention und Aarhus-Konvention von Interesse. Dabei stellt sich auch die Frage, wo Entwicklungen und Diskussionen in den Beitrittsländern, z. B. zur Öffentlichkeitsbeteiligung, auch neue Blickwinkel in den alten EU-Staaten Deutschland und Österreich eröffnen können.

Wie bei den vergangenen Kongressen werden namhafte Fachleute aus dem In- und Ausland die neuesten Entwicklungen und Tendenzen auf dem Gebiet der Umweltprüfung diskutieren. Fachleute aus dem europäischen Ausland werden zu Erfahrungen und Problemen in ihren Ländern referieren; gleichzeitig soll den Gästen aus dem Ausland Einblick in die laufenden Umsetzungsprozesse in Deutschland und Österreich ermöglicht werden.

Der Kongress wird die Themen in Plenumsvorträgen, Diskussionen und Arbeitsgruppen behandeln. Insbesondere wird in $\mathrm{Ar}-$ beitsgruppen zu Schwerpunktthemen Gelegenheit gegeben, einen vertiefenden, fachlichen Dialog zu führen. 
Während des UVP-Kongresses ist eine begleitende Posterpräsentation vorgesehen. In diesem Forum besteht für Ingenieurbüros und weitere Dienstleister die Möglichkeit, ihr Leistungsspektrum im Themenfeld Umweltprüfung vorzustellen. Darüber hinaus informieren Umweltbehörden über ihre Aktivitäten.

\section{Kontakt}

Dr. Frank Scholles

Johanna Scholz

UVP-Gesellschaft e.V.

Institut für Landesplanung und Raumforschung der Universität Hannover

Herrenhäuser Str. 2, 30419 Hannover

Tel.: +49 (0) 511 / 762 - 2617

Fax: +49 (0) 511 / 762 - 5219

E-Mail: uvpkongress@aol.com

Internet: http://www.uvp.de/conf04/welcome.html

॥

\section{netinforum „Klima und Ener- gie" 2004: Emissionshandel aktuell}

München, 8. Oktober 2004

Nach der konkreten Zuteilung der Emissionsberechtigungen Ende September 2004 bietet TÜV SÜD am 8. Oktober in München das netinforum 2004 an. Das Monitoring der Emissionen ist Schwerpunkt der Fachkonferenz.

Nach dem Kabinettsbeschluss zum Nationalen Allokationsplan sind die Weichen für die Zuteilung der Emissionsberechtigungen gestellt. Die Zuteilung der Emissionsberechtigungen an die einzelnen Anlagen wird Ende September 2004 erfolgen. Die einzelnen Unternehmen wissen dann endlich, wie hoch ihr Emissionsbudget ausfällt.

Auf dieser Basis stehen wichtige strategische Entscheidungen an, wobei das Wissen um die aktuelle Datenlage zu den Emissionen eine wichtige Rolle spielen wird. Die aktuellen Entwicklungen und das Monitoring der Emissionen werden daher die Schwerpunkte des netinforum 2004 bilden. netinform wird diese Fachkonferenz am 8. Oktober 2004 in München anbieten.

Weitere Informationen finden Sie bei „http://www.netinform.de“ im Modul „Klima und Energie“.

\section{Anfragen zur Veranstaltung richten Sie bitte an}

Klaus Nürnberger

TÜV SÜD

Westendstraße 199, 80686 München

Tel.: +49 (0) 89 / 5791 - 2752

Fax: +49 (0) 89 / 5791 - 2756

E-Mail: klaus.nuernberger@tuev-sued.de

\section{Construction sector an- nounces conference to stimu- late industry-led research}

Maastricht, The Netherlands, October 14-15, 2004

The European Council for Construction Research, Development and Innovation (ECFREDI), currently coordinating the EU network E-CORE, is to organise a conference to showcase recent construction projects that have benefited form innovation. The event will take place in Maastricht, the Netherlands, on 14 and 15 October.

The conference is organised in the context of increased pressure to ensure the competitiveness of the industry through research and development (R\&D) and innovation, and to move the industry towards a more sustainable and knowledge based economy.

The conference will also serve as a platform for a debate on the future strategy for research and innovation in the construction sector.

ECCREDI also intends to initiate a series of workshops around Europe with a view to preparing for the Seventh Framework Programme.

(Source: CORDIS focus) 
For further information, please contact:

"Building for a European Future" conference organisers

Tel.: +32 - 2 - 7329456

Fax: +32 - 2 - 7320341

E-Mail: info@b4e.org

Internet: http://www.b4e.org

》)

\section{$14^{\text {th }}$ edition of eChallenges}

Vienna, Austria, October 27-29, 2004

The 2004 edition of eChallenges will be held in Vienna, Austria from 27 to 29 October.

e2004, aimed at showcasing European information society technology (IST) research results, will gather practitioners, researchers and government officials to review the achievements of the Fifth Framework Programme (FP5), eEurope2005 and information communication technologies (ICT) initiatives. Participants will also discuss the European Research Area (ERA) and research priorities for the future.

The themes for e2004 are:

- eBusiness - future forms of organisations,

- technology and applications;

- eGovernment services to citizens and business,

- organisational transformation,

- eWork - new working environments,

- eEurope 2005 and ICT take-up by SMEs; international collaboration on IST.

(CORDIS focus)

\section{For more information and registration, please visit}

http://www.echallenges.org/2004

or contact the event secretariat:

E-Mail: edin@adera.fr

\section{Call for Abstracts I Papers $2^{\text {nd }}$ Joint Research Workshop Business and Emissions Trading}

Halle, Germany, November 3 - 5, 2004

\section{Business and Emissions Trading (ET)}

Emissions trading will challenge corporations in an entirely new manner. Switching environmental regulation from hierarchical to market coordination may change corporate internal decision making and processes as well as external strategies. In which ways this will take place, and if it could foster the sustainability of corporate management depends, i.a., on the concrete institutional setting of ET.

Yet such effects are poorly understood even though modeling of tradable permit systems and their comparison with other environmental instruments reaches back more than three decades. There is a need for deeper analysis within different academic fields.

\section{Objective}

The workshop is part of a three years project which intends to bring together young scientists from various backgrounds (economics/ management-/social sciences, theoretical/empirical, descriptive/explicative/prescriptive) to chart the course on new issues for corporate sustainability.

The workshop is a joint workshop with the workgroup "OR in environmental management" within the Society for Operations Research e. V. (GOR).

The workshop will provide an open and creative atmosphere to discuss new ideas and recent findings. It aims to identify research questions for future work in the field of Business and Emissions Trading.

\section{Issues Covered}

The papers may address any relevant area but participants may find guidance amongst the issues listed below:

- How does ET influence structures, processes and decision making within and between 
corporations (e. g. organizational change, monitoring/reporting systems, internal markets and pricing, production planning, risk management, innovation management)?

- How can economic, management and other cultural theories (e.g. institutional/organizational, behavioural/decision/game, capital market/financial/investment, production) help in this context?

- What kind of process and product innovations are stimulated (e. g. prevention/end of pipe, emerging markets)?

- How could ET be further developed to bring the market into corporations?

- Experiences made with (former and running) ET systems and simulations.

- Case study approaches within these issues.

\section{Young Scientists}

The workshop committee particularly invites and encourages young scientists (e.g. research fellows, Dr./PhD students \& fellows, postdocs, habilitation candidates, assistant/junior professors) to take part in the workshop and present a paper.

\section{Language}

The workshop will be held in English. All papers presented will be published in a book which will be in English, too.

\section{Contact}

Dr. Ralf Antes

Martin-Luther-University Halle-Wittenberg

Faculty of Economics

Research Unit Emissions Trading

Große Steinstraße 73, 06099 Halle (Saale), Germany

Tel.: +49 (0) 345 / 5523 - 463

Fax: +49 (0) 345 / 5527 - 199

E-Mail: antes@wiwi.uni-halle.de

Prof. Dr. Peter Letmathe

(Workgroup OR in Environmental Management)

University Siegen, School of Economics

Hölderlinstraße 3, 57068 Siegen, Germany

Tel.: +49 (0) 271 / 740 - 3191

Fax: +49 (0) 271 / 740 - 2776

E-Mail: peter.letmathe@uni-siegen.de

\section{Further Information}

http://www.wiwi.uni-halle.de/lui/bwl/umwelt/

$\ll$

\section{Call for Papers \\ Sustainable Regional Devel- opment - Concepts, Systems and Methods $2^{\text {nd }}$ Nordic Conference on Decision Support}

Lund, Sweden, November 22 - 23, 2004

The overall aims of the conference are to describe, analyse and discuss the benefits and potentials of different concepts, approaches, methods and tools for improving the solutions and related policies in the fields of Sustainable Regional Development as well as their existing problems and challenges in the future.

The programme of the conference is divided into the following four parts. The programme starts with plenary and parallel sessions on the 22 of November including interactive poster presentations aiming at discussing the practice, benefit and potential of different concepts, approaches and methods by presenting practical oriented case studies and projects. On the second day, 2-4 workshops/crashcourses on different software-based instruments (tools) will take place followed by a final plenary session (round table).

The conference aims to attract participants from the fields of Sustainable Regional Development. International, national, regional and local experiences are all equally of interest.

The conference is open to policy-related and entrepreneurial decision makers, practitioners, researchers, students and any other persons interested in research and practice concerning Sustainable Regional Development, to stimulate the exchange of experiences, ideas and views on this subject. Participants from outside of the Nordic countries (Baltic Sea Region) are also very welcome.

Call for Papers, Presentations, Workshops (Crash-Courses) and Poster Session

The conference is focusing on the discussion of different concepts, approaches, methods and 
tools to improve the policy-making-processes in the field of Sustainable Regional Development as well as their existing problems and challenges in the future. The conference is therefore focusing on Applied Science and Practice and therefore welcoming papers from practitioners and experts considering the following topics:

\section{Sustainable Regional Development}

- Concepts and Challenges in the European Perspective

- Common Visions and Strategies of the Baltic Sea Area

- Benchmark of different concepts and describing best-practice-approaches

- Concepts and methods for analysing and evaluating regional innovation and technology potentials

- Concepts and methods for analysing and optimising the existing decision-makingprocesses

The program will comprise plenary, parallel, poster and workshop sessions aiming at

- demonstrating the state-of-the-art in theory and application

- discussing existing problems and challenges and

- discussing the potential of different concepts, approaches, methods and instruments for improving the policy-making processes.

\section{Submission}

Papers and Abstracts may be submitted from July 1, 2004 to September 15, 2004.

\section{Workshops}

The Workshops are aiming at presenting and teaching different software-based instruments (tools) in the sense of practical-oriented crashcourses. Software companies and consultants are welcome to present their new innovative tools.

Proposals for workshops should be submitted using the Workshop Proposal Form found on the conference website. E-mail the completed form directly to the Workshop Chair, Franc Grimm, atinfo@decision-support.info

\section{Contact}

Decision Support Network Secretariat Mr. Franc Grimm, DSN-Co-ordinator TECHNIKZENTRUM Lübeck Seelandstraße 3, 23569 Lübeck, Germany

Tel.: +49 (0) 451 / 3909 - 100

Mobil: +49 (0) 175 - 4339868

Fax: +49 (0) 451 / 3909 - 499

E-Mail:info@decision-support.info

Internet: http://www.decision-support.info

\section{NTA1 - Erste Konferenz des Netz- werks TA „Technik in einer fragilen Welt. Die Rolle der Technikfolgenab- schätzung“"}

\author{
First Announcement and Call for Papers \\ Konstituierung des "Netzwerks TA“
}

\section{Berlin, 24. - 26. November 2004}

Die Konferenz „Technik in einer fragilen Welt. Die Rolle der Technikfolgenabschätzung“ will durch wissenschaftliche Analyse aktueller Entwicklungen in Wissenschaft und Gesellschaft Strategien der Technikgestaltung unter den Rahmenbedingungen einer „fragilen Welt“ aufzeigen. Der Fokus liegt dabei auf den Möglichkeiten der Technikfolgenabschätzung sowie ihre Vernetzung mit anderen Forschungsrichtungen wie Innovationsforschung und Praktischer Ethik.

Die Konferenz wird veranstaltet vom Institut für Technikfolgenabschätzung und Systemanalyse (ITAS, Forschungszentrum Karlsruhe, Prof. A. Grunwald) in Zusammenarbeit mit den Universitäten Bielefeld (Prof. A. Bora) und Stuttgart (Prof. O. Renn) sowie mit Unterstützung des Bundesministeriums für Bildung und Forschung (BMBF).

Ausführliche Informationen zu dieser Veranstaltung sind in den ITAS-News auf S. 152 enthalten. 
International conference I

First Announcement

Images of Science - New interactions between science and society

Amsterdam, The Netherlands, December 6 - 7, 2004

Science has a firmly entrenched image as isolated ivory tower. From their airy fortresses scientists appear to gaze upon the world sometimes hardly aware of the social questions their work arouses. No matter the persistent image, reality is different. Ever more scientists are realising only too well their tower is part of a world that affects them too, and are increasingly sensitive to the social consequences of their work.

Scientists are indeed receptive to the Ethical, Legal and Social Issues (often known as ELSI) related to or resulting from their activities. But how exactly do they respond? Is interaction between science and society across the various disciplines equally strong? Why have ELSI been attracting more attention over recent years? And what exactly is the role of religion and ideology in all of this?

These and other questions on the relationship between science and society are to be reviewed and discussed at the international conference "Images of Science - New Interactions between Science and Society" to be organised by the Rathenau Institute, the Social Sciences Council and the All European Academies of Science (ALLEA) in Amsterdam on 6 and 7 December 2004.

The conference is intended for scientists, politicians, policymakers and other parties interested from European Union states. In plenary sessions and workshops participants will receive an overview of developments over the past 15 years and a fresh look towards the future. Attention will be dedicated to experts' ideas, but (relative) outsiders too will be able to contribute their opinions.

The Conference is organised into the following workshop sessions:

- Workshop 1 - Science and education in the Bologna model

- Workshop 2 - Images of science: past and future
- Workshop 3 - Religion and the future of science

- Workshop 4-Images of the mind

- Workshop 5 - Mediating between science and society

- Workshop 6-Promises of science

- Workshop 7 - Preventing harmful applications : responsibility versus possibility

- Workshop 8 - Elsification and the $\mathrm{E}$ of economy

A special feature of the conference is an "Outsiders Debate“, where prominent opinionleaders with a non scientifical background will give there views on the main topics of the conference and on their relevance to ordinary people.

"Images of Science" is part of a series of events organised during the Netherlands' European Union presidency under the theme of The European Knowledge Society with the support of the Dutch Ministry of Education, Culture and Science.

\section{Contact}

Dr. Koos van der Bruggen

Rathenau Institute

PO Box 85525, 2508 CE The Hague

The Netherlands

Tel.: +31 (0) 703421542

Fax: +31 (0) 703633488

E-Mail: k.vanderbruggen@rathenau.nl

Internet: http://www.rathenau.nl

\section{$《 》$}

Ausführlichere Informationen zu diesen Veranstaltungen sowie Hinweise zu weiteren Tagungen sind dem ständig aktualisierten "Konferenzkalender" auf dem ITAS-Server zu entnehmen (http://www.itas.fzk.de/veranstaltung/inhalt.htm) 